\title{
Investigations and monitoring of deep-seated rock slides in feasibility studies for dam reservoirs
}

\author{
Christian Zangerl ${ }^{1, *}$, Thomas Strauhal ${ }^{1,2}$
}

\author{
${ }^{1}$ University of Natural Resources and Life Sciences, Institute of Applied Geology, Department of Civil Engineering \\ and Natural Hazards, Austria \\ 2 ILF Consulting Engineers Austria GmbH, 6063 Rum, Austria \\ * Corresponding author: christian.j.zangerl@boku.ac.at
}

\begin{abstract}
This contribution presents a brief overview of investigation and monitoring methods which may help to detect and localise deep-seated rock slides in the surroundings of reservoirs. The identification and localisation of critical slopes and ancient/pre-existing rock slides in the early stage of a project (i.e. feasibility study) is essential to avoid endangering the planned infrastructure project and if necessary, adapting the project. The knowledge about deep-seated rock slides has increased over the decades. In particular, new insight was gained about rock slide geometry, kinematics, temporal deformation behaviour, hydrogeology and geomechanics. Major technical and methodical improvements have been made in recent years concerning the successful application of terrestrial and airborne based remote sensing tools to measure 2D/3D slope deformations on surface and to develop high-resolution digital terrain models for detailed geomorphological-geological mapping and geological-geometrical model design.
\end{abstract}

\section{KEYWORDS}

deep-seated rock slides; in-situ investigation; monitoring; dams; reservoirs

Received: 22 June 2020

Accepted: 24 July 2020

Published online: 26 October 2020

Zangerl, C., Strauhal, T. (2020): Investigations and monitoring of deep-seated rock slides in feasibility studies for dam reservoirs. AUC Geographica 55(2), 210-217 https://doi.org/10.14712/23361980.2020.15

(C) 2020 The Authors. This is an open-access article distributed under the terms of the Creative Commons Attribution License (http://creativecommons.org/licenses/by/4.0). 


\section{Introduction}

Worldwide, active and inactive deep-seated rock slides are frequently observed in low-strength rock masses such as foliated metamorphic rocks (Riemer 1995). Generally, these rock slides often affect entire slopes, reach volumes of millions of $\mathrm{m}^{3}$, and usually belong to the compound type of rock slides (Hungr et al. 2014). Active or reactivated over longer periods of time slowly moving rock slides can adversely affect infrastructure such as high- and railway lines, reservoir dams, pressure pipes, pipelines, and settlements due to differential and localised displacements of the ground surface and subsurface (Huang et al. 2016; Gu et al. 2017). Because of the typical slow base activity of many rock slides, they are sometimes either not recognised or their damage potential is underestimated. Even for slow movements the damage can be considerable and the life-cycle of a structure can be reduced, accompanied with a great economic loss (Barla et al. 2010; Petley 2013). In some rare cases there is also the danger of total slope failure and acceleration to extremely high velocities, which in the worst case, can cause dramatic consequences. Reactivation of ancient or pre-existing rock slides or parts thereof is frequently observed and can be triggered by various factors comprising e.g. reservoir infilling or drawdown, toe erosion by flooding, extreme precipitation and snow melt, dynamic loading by earthquakes, construction of a cut slope, or loading the slope in the upper area. Due to the large volume the stabilisation of deep-seated rock slides is difficult, very costly or not feasible at all. In many cases mitigation measures based on groundwater management due to the construction of drainage drifts are possible but the success to reduce the deformation rate is not always guaranteed. Therefore, the identification of critical slopes and ancient rock slides which can endanger the planned infrastructure in an early stage of the project (i.e. feasibility study) is essential. During this early phase a cost-effective adaptation of the project may be possible in many cases.

In the past, thousands of dams and reservoirs were built worldwide and according to the global reservoir and dam database (GRanD) more than 7,000 dams greater than $15 \mathrm{~m}$ in height or with a reservoir volume of more than $0.1 \mathrm{~km}^{3}$ are documented (see Fig. 1, Lehner et al. 2011). In addition, about 3,700 hydropower reservoirs and dams (FHReD) are under construction or in an advanced planning stage. The large number of new dam and reservoir projects for different utilisations require comprehensive planning and hazard assessment of the reservoir slopes, especially early when a feasibility study is performed. This may avoid future landslide induced construction and operation problems.

This contribution presents a brief overview of data and methods which can help to detect, localise, characterise and assess ancient deep-seated rock slides in the surroundings of large dam reservoir projects. In addition, it supports the planning of additional in-situ investigation and monitoring campaigns which are

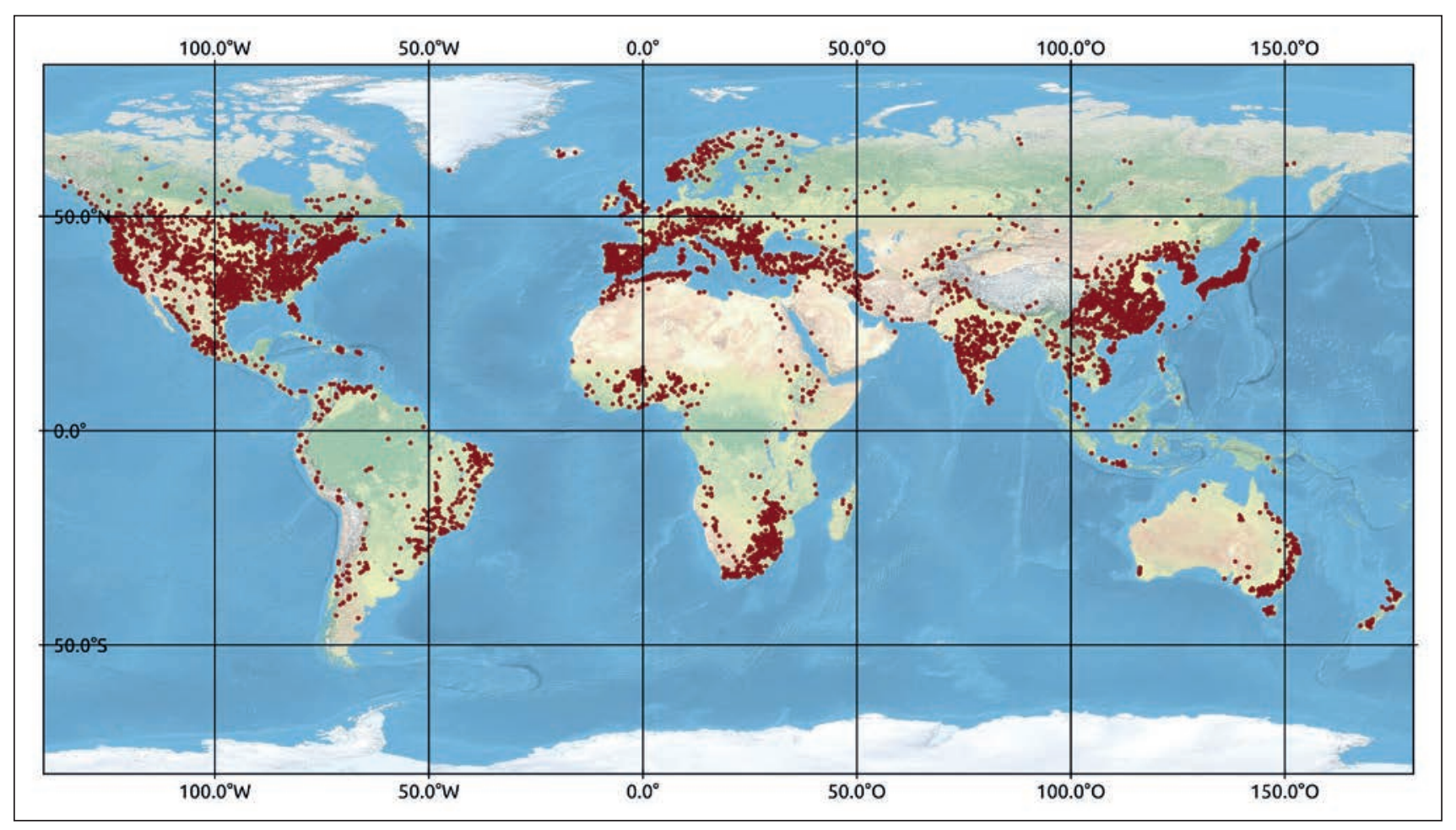

Fig. 1 Global distribution of (dam) reservoirs larger than $0.1 \mathrm{~km}^{3}$ (red dots, Global Reservoir and Dam Database V1.3 [GRanD, globaldamwatch.org], data from Lechner et al. 2011, earth map by Natural Earth. Free vector and raster map data @ naturalearthdata.com). 
fundamental for subsequent slope stability analyses and hazard assessments.

\section{Geodata for rock slide identification and localisation}

In many cases, deep-seated rock slides are not obvious because of their low activities and vegetation cover. A multi-disciplinary approach is required to analyse both size/geometry as well as the movement behaviour of the rock slide consequently. Before beginning with a detailed and expensive field investigation campaign a comprehensive desk study using a geographical information system (GIS) is useful. Therefore, high-resolution digital elevation or terrain models (DEM, DTM) usually obtained from airborne laser scanning (ALS) campaigns and supplemented by multi-temporal high-quality aerial images from airborne and UAV campaigns are needed for the project area. Because of the importance of high-resolution DEMs for landslide analyses these data should be a standard nowadays (Tab. 1). However, there are still recently published studies with reference to landslides and reservoirs with no high-quality DEMs being presented, but rather a focus is given on linear subsurface investigations by boreholes. Only by combining both, geomorphological-geological mapping on surface based on high-resolution DEMs (obtained by laser scanning or photogrammetry) and subsurface investigations a proper three-dimensional rock slide model can be obtained. Commonly, deep-seated rock slides are characterised by the formation of different slabs with variable sizes, movement velocities, and internal shear zones (Fig. 2). Geomechanically, these shear zones are of primary concern for stability analyses or predictions relating to future deformations. The material is the result of cataclasis and fragmentation of the rock during shearing and possesses soil-like mechanical and hydraulic properties. Stability and deformation behaviour of the rock slides is influenced by hydro-mechanical properties of these zones. Scarps mapped at ground surface should be correlated with basal and internal shear zones encountered in the subsurface (e.g. in drillings) to get a better understanding of the dimensions and geometry of the rock slide mass. GIS processed DEMs

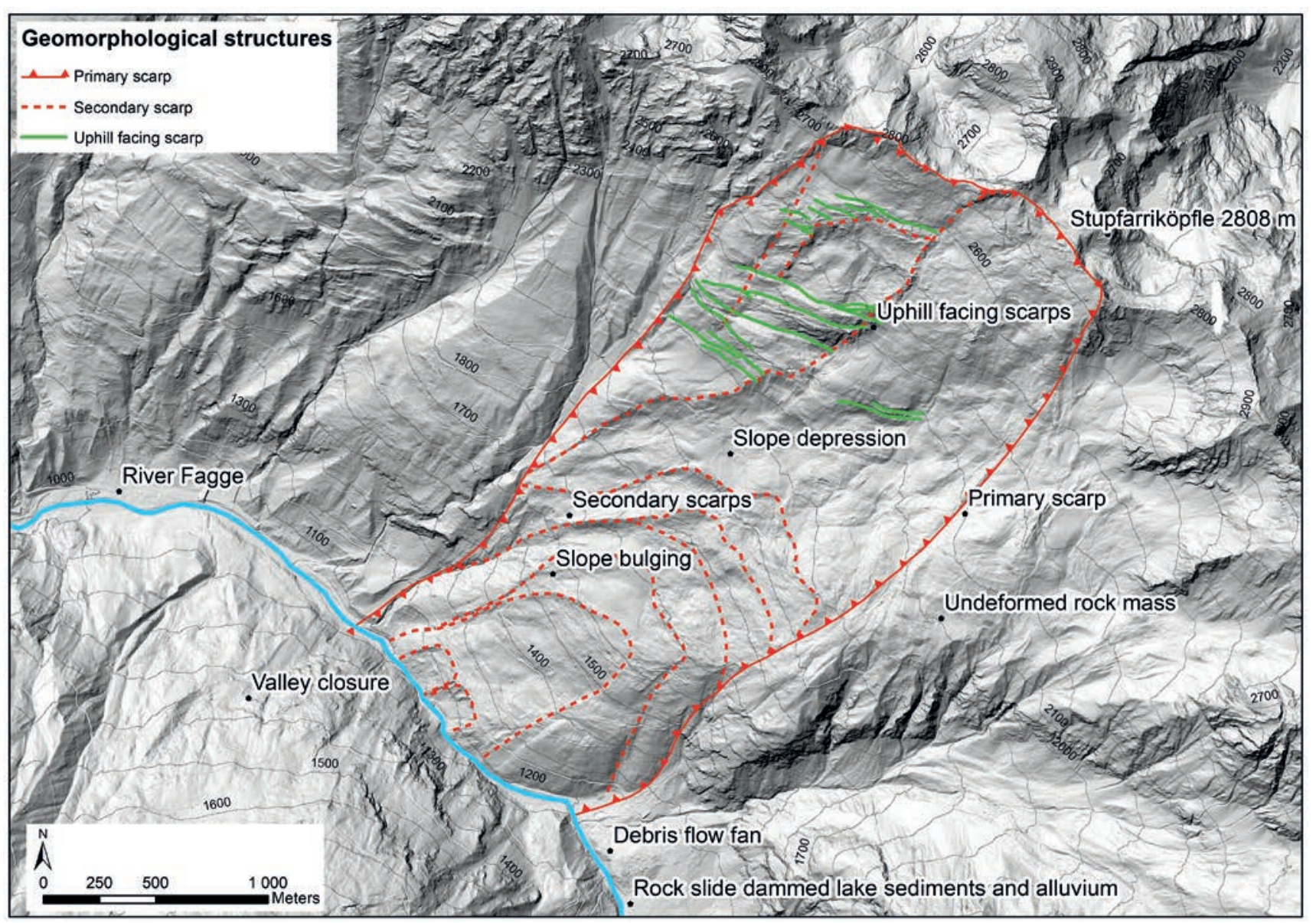

Fig. 2 Hillshade of a deep-seated rock slide in metamorphic rock showing the main, secondary and uphill facing scarps of sliding slabs, and rock slide dammed lake sediments in the upstream (Stupfarri rockslide in the Kaunertal valley, Austria, DEM source: TIRIS - Amt der Tiroler Landesregierung). 
Tab. 1 Types of geodata for rock slide identification and localisation.

\begin{tabular}{|l|l|l|}
\hline Type of data & Description & Method \\
\hline $\begin{array}{l}\text { Digital elevation } \\
\text { Orrain model }\end{array}$ & High-resolution DEM/DTM with a raster size $\leq 1 \mathrm{~m}$ & $\begin{array}{l}\text { Airborne and terrestrial laser scanning, } \\
\text { UAV - based photogrammetry }\end{array}$ \\
\hline Optical satellite images & $\begin{array}{l}\text { Digital high-resolution ortho-images, raster size }<20 \mathrm{~cm}, \\
\text { ideally multi-temporal }\end{array}$ & Optical imagery by plane, helicopter or UAV \\
\hline Topographic maps & $\begin{array}{l}\text { Ground relief, drainage, forest cover, administrative areas, populated } \\
\text { areas, transportation routes and facilities, man-made features }\end{array}$ & Cartographical mapping methods \\
\hline Regional geological maps & Pre-existing maps of the region (Scale 1:50,000 to 1:200,000) & Geological field mapping \\
\hline Detailed geological maps & $\begin{array}{l}\text { Detailed geological mapping of the project area } \\
\text { (Scale } 1: 1000 \text { to } 1: 10,000)\end{array}$ & Geological field mapping \\
\hline Landslide inventory maps & $\begin{array}{l}\text { Pre-existing maps of landslide types and features according } \\
\text { to accepted classification systems }\end{array}$ & Combination of desk study and field survey \\
\hline Historic records & Age data and chronology of landslides & Field survey, archives, age-dating \\
\hline
\end{tabular}

e.g. one-light-source or multi-directional hillshades, applying advanced filtering techniques, slope roughness and inclination are the basis to perform accurate and detailed geomorphological and geological terrain analyses and mappings (Reuter et al. 2009). Primary aim of a desk study is to detect structures and slope geometries which resulted from gravitational slope deformations. In particular, multi-directional hillshades highlight the terrain surface very plastically. Typically, primary and secondary scarps, uphill facing scarps, extensional cracks, slope bulging and depressions, the boundary between the rock slide and the undeformed rock mass, increased fracture density and rock mass loosening, etc. are clear indicators for deep-seated slope movements (see Fig. 2). Additionally, optical satellite images, pre-existing geological and topographical maps can be analysed during the desk study with the purpose of planning the field survey.

\section{Geological-geomorphological field survey}

The subsequent geological-geomorphological field survey is based on the high-resolution DEMs and high-quality ortho-images and include the verification of the observations from the desk study as well as the field-based mapping of geological (e.g. soil, rock, faults, joint network, springs and streams) and geomorphological features which are not obvious in remote sensing data (Table 1). According to the mapping results the areal extent of a rock slide (i.e. head scarps, lateral flanks and further landslides features, see WP/WLI UNESCO Working Party on World Landslide Inventory 1993) and surface boundaries of slabs are determined which enable a first and rough estimation of the thickness. The spatial extension, the shape of the primary scarps and the internal structures of the rock slide provide information about the kinematics (e.g. translational, rotational, compound failure).
Mapping of all features (including slabs) is essential because of the complex geometry i.e. slab formation and movement behaviour of some rock slides (e.g. Zangerl et al. 2010). Further, it allows the classification of the evolution and activity stage in some cases.

\section{Deformation monitoring}

The choice of the investigation methods to monitor the deformation behaviour of a rock slide depends on project requirements and local circumstances. Depending on the particular project phase, surface and/or subsurface measurements are needed which again should be performed continuously (e.g. to detect acceleration phases and their triggers) or episodically only. The slow movement rates of only a few millimetres or centimetres per year of some rock slides in combination with small time constraints given by many early project specifications are the reasons why accurate deformation monitoring systems with low detection limits are required. Conclusively, depending on the monitoring method, rock slide velocity and size, a sufficiently long measuring period, sometimes more than a year, need to be planned to obtain significant data. For example, the detection of slope displacements for a $1000 \mathrm{~m}$ high rock slide slope with an annual displacement rate of $\mathrm{mm}$ to a few $\mathrm{cm}$ is challenging when reliable deformation data above the measuring accuracy should be attained in a short period. For some projects, there is a mismatch between the time span prescribed for project planning and the time span needed to get reliable information about the rock slide activity. Furthermore, it is important to note that the activity behaviour of a rock slide can change during the live-cycle of an infrastructure and the occurrence of unexpected acceleration phases should be considered. 
Large rock slides are a challenge for monitoring due to the large measuring distances, but recent developments of remote sensing techniques provide new useful tools (Tab. 2). Satellite-based radar interferometry (InSAR) can be applied to measure areal slope deformations when vegetation cover is low and slope exposure is ideal with regard to satellite movement (Casagli et al. 2017; Zhang et al. 2013). A particular advantage of this remote sensing method is the possibility to detect deformations as far back as to the nineties, since from that time radar-images are available.

For larger rock slide velocities (i.e. decimeters to metres per year) airborne-based photogrammetric and laser scanning methods are available should be applied to get dense point clouds and high-resolution DEMs. If multi-temporal scanning and imaging was done displacement maps can be obtained. New advanced methods based on image processing and feature tracking of terrain breaklines enable the extraction of 3D displacement vectors of the surface (Fey et al. 2015; Jaboyedoff et al. 2012; Razak et al. 2011).

Terrestrial radar interferometry (TRI, GB-InSAR) can also be applied by installing the system on the ground mostly opposite of the slope to be monitored. The radar interferometry method is able to detect and quantify deformations from repeat monitoring setups of extremely slow moving rock walls and slopes (millimetres per year) to slow/moderate movements (metres per day) acquired during episodic and continuous measurement campaigns (Bardi et al. 2014; Caduff et al. 2015; Crosta et al. 2013; Cruden and Varnes 1996).

Terrestrial laser scanning (TLS) represents a further useful method for spatial change detection analyses and deformation monitoring (Fey and Wichmann 2017; Jaboyedoff et al. 2012). The long-range TLS method enable contact-free measurements of the terrain, and depending on the distance, is able to measure slope deformations of decimetres per year. Although TLS is less accurate than GB-InSAR, it has the advantage that measurements can also be carried out in forested and vegetated areas by getting the terrain surface recorded.

UAV-based photogrammetry is a cost- and time-effective method which can be applied to monitor rock slide deformations in a sparsely vegetated area by the acquisition of multi-temporal high-resolution images (Cardenal et al. 2008). Image matching and correlation algorithms deliver time-series of surface deformation models which enable the determination of movement directions, velocity fields, volume balances and geomorphological terrain changes (Casagli et al. 2017). Although this method is fast and inexpensive, a major disadvantage is that areas with dense vegetation cover cannot be successfully recorded.

Traditional total station or differential global positioning system (GNSS) measurements are reliable methods to obtain 3D displacement vectors of
Tab. 2 Selected slope deformation monitoring methods.

\begin{tabular}{|c|c|}
\hline Method & Description \\
\hline $\begin{array}{l}\text { Airborne laser } \\
\text { scanning (ALS) }\end{array}$ & $\begin{array}{l}\text { Survey by UAV or aircraft, dense point clouds, } \\
\text { area-based data, can penetrate vegetation cover, } \\
\text { detection of displacements in the range of } \mathrm{dm} \text { to } \mathrm{m}\end{array}$ \\
\hline $\begin{array}{l}\text { Terrestrial laser } \\
\text { scanning (TLS) }\end{array}$ & $\begin{array}{l}\text { By tripod from ground, dense point cloud, } \\
\text { area-based data, can penetrate vegetation cover, } \\
\text { detection of displacements in the range of } \mathrm{cm} \\
\text { to } \mathrm{dm}\end{array}$ \\
\hline $\begin{array}{l}\text { Satellite-based } \\
\text { InSAR }\end{array}$ & $\begin{array}{l}\text { Areal displacement, sensitive to vegetation cover, } \\
\text { detection of displacements in the range of } \mathrm{cm} \\
\text { to } \mathrm{dm}\end{array}$ \\
\hline $\begin{array}{l}\text { Terrestrial } \\
\text { radar- } \\
\text { interferometry }\end{array}$ & $\begin{array}{l}\text { Areal displacement, sensitive to vegetation cover, } \\
\text { permanent monitoring, detection of displacements } \\
\text { in the range of } \mathrm{mm} \text { to } \mathrm{m}\end{array}$ \\
\hline $\begin{array}{l}\text { UAV-Photo- } \\
\text { grammetry }\end{array}$ & $\begin{array}{l}\text { Areal displacement, sensitive to vegetation cover, } \\
\text { detection of displacements in the range of } \mathrm{cm} \\
\text { to } \mathrm{dm}\end{array}$ \\
\hline $\begin{array}{l}\text { GNSS, } \\
\text { Tachymetry, } \\
\text { Levelling }\end{array}$ & $\begin{array}{l}\text { Manually or automatically, pointwise measurement } \\
\text { with reflectors, 3D displacement vectors, detection } \\
\text { of displacements in the range of } \mathrm{mm} \text { to } \mathrm{cm}\end{array}$ \\
\hline Inclinometer & $\begin{array}{l}\text { Drillings and tube installations needed, exact } \\
\text { detection and localisation of active shear zones } \\
\text { (rupture planes), detection of displacements in the } \\
\text { range of } \mathrm{mm} \text { to } \mathrm{cm} \text {, rapid loss of the inclinometer } \\
\text { device through shearing of the borehole, expensive, } \\
\text { preliminary rock slide model required to define } \\
\text { borehole location and depth correct, detection } \\
\text { of displacements in the range of } \mathrm{mm} \text { to dm }\end{array}$ \\
\hline
\end{tabular}

individual targets installed on a rock slide (Carla et al. 2019). When these systems are automated they form robust permanent monitoring and warning systems. Generally, pointwise inclination data of 3D displacement vectors are particularly useful to develop preliminary kinematical models of a rock slide (i.e. rotational or planar sliding mechanism).

Results from exploration campaigns confirmed that rock slide deformation accumulates primarily along basal and internal shear zones (Noveraz 1996; Zangerl et al. 2015). Detection of these shear zones is crucial to establish a sound geometrical model and to determine the extension of the rock slide into the depths. Thus line-shaped measurements along a vertical borehole by inclinometer devices, installed for episodic or continuous (i.e. in-place systems) measurement are needed (Stark and Choi 2008). During installation a solid mechanical infill between the inclinometer tube and the fractured rock mass is required to transmit the shear displacements to the tube and to obtain accurate measurements. In order to get interpretable measurement results sufficient long time intervals should be planned between the baseline and the follow-up measurements for very slow and deep-seated rock slides. Incorrect conclusions of measured data are quite common, especially for deep installations, and therefore a critical assessment considering the geological model and the application of systematic error correction methods is recommended (Mikkelsen 2003; Willenberg et al. 2003). 


\section{Geological-geotechnical subsurface characterization}

Subsurface in-situ investigations are usually not part of an initial feasibility study but may become important when potential dam foundation sites need assessment concerning the occurrence of ancient deep-seated rock slides. Therefore, a more detailed study is required to investigate the geological and hydrogeological characteristics of rock slides. Although costly, subsurface investigations based on core drillings with borehole loggings in combination with inclinometer measurements and/or investigation drifts are required to improve the rock slide model obtained solely from surface data and to localise the basis/ thickness of the rock slide mass and shear zones. If the rock slide is inactive or extremely slow inclinometer measurements are not able to localise shear zones, at least not within a reasonable period of time. Under such conditions a detailed geological core logging is needed provided that the drilling quality is high and the core recovery high. Core drillings into deep-seated rock slides are technically challenging and should be done by experienced drilling companies to maximize the gain in knowledge. Fluctuations of the rock quality designation values (RQD) between low and high, increased fracture densities, weathering and coating of fracture surfaces, and sections of fault-zone like totally crushed material (clay to gravel grain fraction) are typical characteristics of rock slide masses (Zangerl et al. 2010, 2014, 2015). Very low RQD values are usually observed around the basal contact or in the surrounding of internal shear zones. It should be noted that the degree of internal rock mass fragmentation and loosening of a rock slide is often related to the accumulated amount of slope displacements.

Geophysical investigations based on advanced data processing allows a further improvement of the geological-geometrical model. Seismic methods by combining reflection, refraction and tomography provide usually meaningful results of the subsurface, but require a qualitative interpretation of the results, ideally by joint analyses with borehole data (Brückl and Brückl 2006; Brückl et al. 2006; Frei and Keller 2000).

\section{Hydrogeological characterization}

If a dam reservoir is planned in a rock slide prone area information about the hydrogeological situation is particularly mandatory. This is especially true since the reservoir may influence the groundwater flow system within the slope differently (Strauhal et al. 2016; Zangerl et al. 2015). Monitoring of piezometric heights in boreholes is suggested to assess groundwater flow systems and time-depending pore pressure distributions, as well as the hydro-mechanical coupled characteristics (Crosta et al. 2014). Typically, the complex and heterogeneous hydrogeological situation of a rock slide suggests the installation of several monitoring piezometers at various locations in the slope (Moore 1999). Groundwater may occur in highly fractured sections which can hardly be predicted in many cases. Furthermore, hydrogeological rock mass parameters such as hydraulic conductivity or storativity values at in-situ scale can be determined for example by borehole-based hydraulic packer tests, both for the bedrock and the rockslide mass. Again, a high number of tests is required because of the typically heterogeneous nature due to fracturing and fragmentation of deep-seated rock slides. These parameters are required to analyse and forecast the future impact of initial reservoir impounding and level fluctuations on slope behaviour. The detection of water barriers with low hydraulic conductivities, such as compacted till covers or thick fault gouge-shear zones is highly relevant in this context, given that they could have a strong impact on time-depending groundwater fluctuations.

\section{Discussion and Conclusion}

In the future the number of large-scale dam and reservoir projects will increase. Many of them will be planned in rock slide-prone areas. In an early planning stage comprehensive feasibility studies for dam reservoirs are essential to avoid stability problems of dam foundations or reservoir slopes. All the ancillary data and methods mentioned above focus on the detection and localisation of ancient i.e. pre-existing deep-seated rock slides which can adversely affect infrastructure in the surrounding of dam reservoirs. Experiences show that multidisciplinary approaches including high-resolution digital elevation models beside deformation models and instrumented core drillings are the basis for a successful identification and assessment. Data from geomorphological-geological surveys, surface and subsurface investigations, if possible, and deformation measurements are needed for a comprehensive feasibility study i) to identify, localise and map ancient rock slides and landslide-prone areas, ii) to establish preliminary geological-geometrical rock slide models by considering its complexity due to the formation of different slabs, iii) to assess the present activity of the rock slides, and iv) to provide data for subsequent more detailed planning and investigation. All these data form the basis for further project planning and risk assessments, whereby the importance of a high-resolution digital elevation model with a raster size $<1 \mathrm{~m}$ must be emphasized. The early stage of a dam reservoir project is also ideal for hydrogeological, geomechanical and hydro-mechanical coupled numerical modelling (Alonso and Pinyol 2011). All of the abovementioned data should be implemented in detailed numerical models to analyse the potential impact of the first infillings, water level 
draw downs and later infillings of a planned reservoir on the pore pressure distribution and the resulting change in slope behaviour. Both stationary and transient modelling should be carried out because of the various filling stages of a reservoir. Despite the complex three-dimensional landslide geometries and heterogeneous and anisotropic characteristics, this step is usually done by two-dimensional models currently. Further developments in this context are expected in the future.

Deep-seated rock slides which were newly formed as first-time failures are not considered herein. Potential first-time slope failures are much more difficult to locate and the assessment of the spatial extent and thickness is therefore a challenge and require additional efforts and methodical approaches.

\section{References}

Alonso, E. E., Pinyol, N. M. (2011): Landslides in reservoirs and dam operation. In: Dam Maintenance and Rehabilitation II, Romeo García et al. (eds.), 2nd International Congress on Dam Maintenance and Rehabilitation, Zaragoza, Spain, Taylor and Francis Group, London, 3-27, https://doi.org/10.1201 /9780415616485-3.

Bardi, F., Frodella, W., Ciampalini, A., Bianchini, S., Del Ventisette, C., Gigli, G., Fanti, R., Moretti, S., Basile, G., Casagli, N. (2014): Integration between ground based and satellite SAR data in landslide mapping: The San Fratello case study. Geomorphology 223, 45-60, https://doi.org/10.1016/j.geomorph.2014.06.025.

Barla, G., Antolini, F., Barla, M., Mensi, E., Piovano, G., (2010): Monitoring of the Beauregard landslide (Aosta Valley, Italy) using advanced and conventional techniques. Engineering Geology 116, 218-235, https://doi.org /10.1016/j.enggeo.2010.09.004.

Brückl, E., Brückl, J. (2006): Geophysical models of the Lesachriegel and Gradenbach deep-seated mass movements (Schober range, Austria). Engineering Geology 83(1-3), 254-272, https://doi.org/10.1016 /j.enggeo.2005.06.035.

Brückl, E., Brunner, F.K., Kraus, K. (2006): Kinematics of a deep seated landslide de-rived from photogrammetric, GPS and geophysical data. Engineering Geology 88, 149-159, https://doi.org/10.1016/j.enggeo.2006 .09 .004 .

Caduff, R., Schlunegger, F., Kos, A., Wiesmann, A. (2015): A review of terrestrial radar interferometry for measuring surface change in the geosciences. Earth Surf. Process, Landforms 40, 208-228, https://doi.org /10.1002/esp.3656.

Cardenal, J., Mata, E., Perez-Garcia, J. L., Delgado, J., Andez, M., Gonzalez, A., Diaz-de-Teran, J. R. (2008): Close range digital photogrammetry techniques applied to landslide monitoring. International Archives of Photogrammetry, Remote Sensing and Spatial Information Sciences 37 (Part B8).

Carlà, T., Tofani, V., Lombardi, L., Raspini, F., Bianchini, S., Bertolo, D., Thuegaz, P., Casagli, N. (2019): Combination of GNSS, satellite InSAR, and GBInSAR remote sensing monitoring to improve the understanding of a large landslide in high alpine environment. Geomorphology 335, 62-75, https://doi.org/10.1016/j.geomorph .2019.03.014.

Casagli, N., Frodella, W., Morelli, S. et al. (2017): Spaceborne, UAV and ground-based remote sensing techniques for landslide mapping, monitoring and early warnin. Geoenvironmental Disasters 4(9), https://doi.org /10.1186/s40677-017-0073-1.

Crosta, G. B., di Prisco, C., Frattini, P. et al. (2014): Chasing a complete understanding of the triggering mechanisms of a large rapidly evolving rockslide. Landslides 11 , 747-764, https://doi.org/10.1007/s10346-013-0433-1.

Cruden, D. M., Varnes, D. J. (1996): Land-slide Types and Processes. In: Turner, A. K. et al. (eds.), Landslides: Investigation and Mitigation, 36-75, Washington.

Fell, R., Hungr, O., Leroueil, S., Riemer, W. (2000): Geotechnical engineering of the stability of natural slopes, and cuts and fills in soil. GeoEng2000 International Conference on Geotechnical and Geological Engineering, Aust. Geomech. Soc., Melbourne, Australia.

Fey, C., Rutzinger, M., Wichmann, V., Prager, C., Bremer, M., Zangerl, C. (2015): Deriving 3D displacement vectors from multi-temporal airborne laser scanning data for landslide activity analyses. GisSience and Remote Sensing 52, 437-461, https://doi.org/10.1080 /15481603.2015.1045278.

Fey, C., Wichmann, V. (2017): Long-range terrestrial laser scanning for geomorphological change detection in alpine terrain - handling uncertainties. Earth Surface Processes and Landforms 42, 789-802, https://doi.org /10.1002/esp.4022.

Frei, W., Keller, L. (2000): Hybride Seismik - eine verbesserte Methode zur Verwertung des Aus-sagepotentials seismischer Daten. Bull. angew. Geol. 5(2), 229-236.

Gu, D. M., Huang, D., Yang, W. D. et al. (2017): Understanding the triggering mechanism and possible kinematic evolution of a reactivated landslide in the Three Gorges Reservoir. Landslides 14, 2073-2087, https://doi.org /10.1007/s10346-017-0845-4.

Huang, Q., Wang, J., Xue, X. (2016): Interpreting the influence of rainfall and reservoir infilling on a landslide. Landslides 13, 1139-1149, https://doi.org/10.1007 /s10346-015-0644-8.

Hungr, O., Leroueil, S., Picarelli, L. (2014): The Varnes classification of landslide types, an update. Landslides 11, 167-194, https://doi.org/10.1007/s10346 -013-0436-y.

Jaboyedoff, M., Oppikofer, T., Abellan, A., Derron, M. H., Loye, A., Metzger, R. (2012): Use of LIDAR in landslide investigations: A review. Natural Hazards, 61, 1-24, https://doi.org/10.1007/s11069-010-9634-2.

Lehner, B., Liermann, R. C., Revenga, C., Vörösmarty, Ch., Fekete, B., Crouzet, P., Döll, P., Endejan, M., Frenken, K., Magome, J., Nilsson, C., Robertson, J. C., Rodel, R., Sindorf, N., Wisser, D. (2011): High-resolution mapping of the world's reservoirs and dams for sustainable river-flow management. Frontiers in Ecology and the Environment 9(9), 494-502, https://doi.org/10.1890/100125.

Mikkelsen, P. E. (2003): Advances in Inclinometer Data Analysis. In: Symposium of Field Measurements in Geomechanics. Oslo, Norway, 555-567, https://doi.org /10.1201/9781439833483.ch73. 
Moore, D. P. (1999): Rock slopes and reservoirs - lessons learned. Canada: 13. Annual Vancouver Geotechnical Society Symposium; Vancouver, BC (Canada), Vancouver Geotechnical Society, 1-18.

Noverraz, F. (1996): Sagging or deep-seated creep: fiction or reality? In: Senneset (Ed.), 7th International Symposium on Landslides. Balkema, Rotterdam, 821-828.

Petley, D. N. (2013): Global losses from landslides associated with dams and reservoirs, in: International Conference on Vajont 1963-2013: Thoughts and Analyses after 50 years since the Catastrophic Landslide, edited by: Genevois, R. and Prestininzi, A., Italian Journal of Engineering Geology and Environment, Book Series 6, 63-71.

Razak, K. A., Straatsma, M. W., van Westen, C. J., Malet, J.-P., de Jong, S. M. (2011): Airborne laser scanning of forested landslides characterization: Terrain model quality and visualization. Geomorphology 126(1-2), 186-200, https://doi.org/10.1016/j.geomorph.2010.11.003.

Reuter, H. I., Hengl, T., Gessler, P., Soille, P. (2009): Chapter 4 - Preparation of DEMs for geomorphometric analysis. Developments in Soil Science 33, 87-120, https://doi.org/10.1016/S0166-2481(08)00004-4.

Riemer, W. (1995): Keynote paper: Landslides and reservoirs. In: D. H. Bell (Ed), 6th International Symposium on Landslides, Christchurch, Balkema, Rotterdam, 1973-2004.

Strauhal, T., Loew, S., Holzmann, M., Zangerl, C. (2016): Detailed hydrogeological analysis of a deep-seated rockslide at the Gepatsch reservoir (Klasgarten, Austria). Hydrogeology Journal 24, 349-371, https://doi. org/10.1007/s10040-015-1341-3.

Stark, T. D., Choi, H. (2008): Slope inclinometers for landslides. Landslides 5, 339, https://doi.org/10.1007 /s10346-008-0126-3.

WP/WLI UNESCO Working Party on World Land-slide Inventory (1993): Multilingual Landslide Glosary. The
Canadian Geotechnical Society, BiTech Publishers Ltd. Richmond, Canada.

Willenberg, H., Evans, K. F., Eberhardt, E., Loew, S. (2003): Monitoring complex rock slope instabilities - correction and analysis of inclinometer/extensometer surveys and integration with surface displacement data. In: F. Myrvoll (ed.), 6th International Symposium on Field Measurements in Geomechanics, Oslo: Balkema, 393-400, https://doi.org/10.1201/9781439833483 .ch52.

Zangerl, C., Eberhardt, E., Perzlmaier, S. (2010): Kinematic behaviour and velocity characteristics of a complex deep-seated crystalline rock slide system in relation to its interaction with a dam reservoir. Engineering Geology 112, 53-67, https://doi.org/10.1016/j.enggeo.2010 .01 .001 .

Zangerl, C., Holzmann, M., Perzlmaier, S., Engl, D., Strauhal, T., Prager, C., Steinacher, R., Molterer, S. (2014): Characterisation and kinematics of deep-seated rock slides in foliated metamorphic rock masses. In: Lollino, G., Giordan, D., Thuro, K., Carranza-Torres, C., Wu, F., Marinos, P., Delgado, C. (eds.), Engineering geology for society and territory 2. Springer, Heidelberg, Germany, 571-577, https://doi.org/10.1007 /978-3-319-09057-3_94.

Zangerl, C., Holzmann, M., Perzlmeier, S., Strauhal, T. (2015): Geomechanics and Hydrogeology of Deep-seated Rock Slides in the Surroundings of Large Reservoirs. In: The International Society for Rock Mechanics (ISRM), Proceedings of the 13th International Congress of Rock Mechanics, ISRM Congress 2015 - Innovations in Applied and Theoretical Rock Mechanics.

Zhang, D., Wang, G., Yang, T. et al. (2013): Satellite remote sensing-based detection of the deformation of a reservoir bank slope in Laxiwa Hydropower Station, China. Landslides 10, 231-238, https://doi.org /10.1007/s10346-012-0378-9. 